\title{
Laboratory Investigations in Support of Carbon Dioxide-Limestone Sequestration in the Ocean
}

\author{
Semi-Annual Technical Progress Report \\ for the period \\ 7/9/2004-1/8/2005
}

\section{Dan Golomb, Eugene Barry, David Ryan, Carl Lawton Co-Principal Investigators \\ Peter Swett, Huishan Duan, Matthew Woodcock \\ Research Assistants}

Submitted April 2005

submitted to

US Department of Energy

National Energy Technology Laboratory

Dr. Heino Beckert

Project Officer

Co-operative Agreement DE-FC26-02NT41441

UML Project ST-105691

University of Massachusetts Lowell, Lowell, MA 01854 


\section{DISCLAIMER}

This report was prepared as an account of work sponsored by an agency of the United States Government. Neither the United States Government nor any agency thereof, nor any of their employees, makes any warranty, express or implied, or assumes any legal liability or responsibility for the accuracy, completeness, or usefulness of any information, apparatus, product, or process disclosed, or represents that its use would not infringe privately owned rights. Reference herein to any specific commercial product, process, or service by trade name, trademark, manufacturer, or otherwise does not necessarily constitute or imply its endorsement, recommendation, or favoring the United States Government or any agency thereof. The views and opinions of authors expressed herein do not necessarily state or reflect those of the United States government or any agency thereof. 


\title{
Laboratory Investigations in Support of Carbon Dioxide-Limestone Sequestration in the Ocean
}

\begin{abstract}
This semi-annual progress reports includes further findings on $\mathrm{CO}_{2}$-in-Water $(\mathrm{C} / \mathrm{W})$ emulsions stabilized by fine particles. In previous reports we described $\mathrm{C} / \mathrm{W}$ emulsions using pulverized limestone $\left(\mathrm{CaCO}_{3}\right)$, flyash, and a pulverized magnesium silicate mineral, lizardite, $\mathrm{Mg}_{3} \mathrm{Si}_{2} \mathrm{O}_{5}(\mathrm{OH})_{4}$, which has a similar composition as the more abundant mineral, serpentine. All these materials formed stable emulsions consisting of droplets of liquid or supercritical $\mathrm{CO}_{2}$ coated with a sheath of particles dispersed in water.

During this semi-annual period we experimented with pulverized beach sand (10 $-20 \mu \mathrm{m}$ particle diameter). Pulverized sand produced an emulsion similar to the previously used materials. The globules are heavier than water, thus they accumulate at the bottom of the water column. Energy Dispersive X-ray (EDX) analysis revealed that the sand particles consisted mainly of $\mathrm{SiO}_{2}$. Sand is one of the most abundant materials on earth, so the economic and energy penalties of using it for ocean sequestration consist mainly of the cost of transporting the sand to the user, the capital and operating costs of the pulverizer, and the energy expenditure for mining, shipping and grinding the sand. Most likely, sand powder would be innocuous to marine organisms if released together with $\mathrm{CO}_{2}$ in the deep ocean.

We examined the effects of methanol $(\mathrm{MeOH})$ and monoethanolamine (MEA) on emulsion formation. These solvents are currently used for pre- and post-combustion capture of $\mathrm{CO}_{2}$. A fraction of the solvents may be captured together with $\mathrm{CO}_{2}$. A volume fraction of $5 \%$ of these solvents in a mix of $\mathrm{CO}_{2} / \mathrm{CaCO}_{3} / \mathrm{H}_{2} \mathrm{O}$ had no apparent effect on emulsion formation. Previously we have shown that a $3.5 \%$ by weight of common salt $(\mathrm{NaCl})$ in water, simulating seawater, also had no appreciable effect on emulsion formation.

We investigated the formation of inverted emulsions, where water droplets coated with pulverized materials are dispersed in liquid or supercritical $\mathrm{CO}_{2}$. This is a Water-in$\mathrm{CO}_{2}$ emulsion (W/C) stabilized by particles. For a W/C emulsion it is necessary to employ hydrophobic particles, where the particles are primarily wetted by $\mathrm{CO}_{2}$. We used the following hydrophobic particles: carbon black, coal dust, and Teflon. All materials were either obtained as fine particles or ground to $10-20 \mu \mathrm{m}$ size. All these hydrophobic particles produced a stable W/C emulsion.
\end{abstract}




\section{TABLE OF CONTENTS}

ABSTRACT 3

EXPERIMENTAL 5

(a) High Pressure Batch Reactor 5

(b) In-house Preparation of Fine Particles $\quad 5$

(c) Materials

RESULTS

(a) $\mathrm{CO}_{2}$-in-Water Emulsion $(\mathrm{C} / \mathrm{W}) \quad 6$

(b) Water-in- $\mathrm{CO}_{2}$ Emulsion (W/C) 6

(c) Effect of Impurities on Emulsion Formation 6

$\begin{array}{ll}\text { DISCUSSION } & 7\end{array}$

PLANS FOR THE NEXT PERIOD $\quad 8$

(a) Apparatus Additions and Modifications $\quad 8$

(b) Measurements in High Pressure Batch Reactor 8

(c) Measurements in High Pressure Flow Reactor with Static Mixer 9

$\begin{array}{ll}\text { CONCLUSION } & 9\end{array}$

$\begin{array}{ll}\text { REFERENCES } & 9\end{array}$

$\begin{array}{ll}\text { PUBLICATIONS } & 9\end{array}$

$\begin{array}{ll}\text { ILLUSTRATIONS } & 10\end{array}$ 


\section{EXPERIMENTAL}

\section{(a) High Pressure Batch Reactor}

For the experiments in the reporting period the new and improved High Pressure Batch Reactor (HPBR) with view windows described in the previous semi-annual report was used. We modified a laboratory vertical microscope, so to be able to mount it horizontally on the view cell window. The microstructure of the globules can be seen through the eyepiece up to 40x magnification. The microscope has an attached video camera for recording the observations. The usual procedure is to prepare a slurry of the particles in water, add a measured volume of the slurry to the HPBR through an opening, close the opening, then add a measured volume of liquid or supercritical $\mathrm{CO}_{2}$ by means of a syringe pump. The temperature of the HPBR is regulated by surrounding it with dry ice chips, or by a heat gun. The ingredients are thoroughly mixed with a magnetic stir bar.

The total volume of the HPBR is $85 \mathrm{~mL}$. Unless otherwise indicated, the proportions of the ingredients were as follows: $10 \mathrm{~g}$ of particulate matter suspended in $65 \mathrm{~mL}$ water, $\sim 18-20 \mathrm{~mL}$ (balance) liquid $\mathrm{CO}_{2}$. Pressure $17.2 \mathrm{MPa}$, temperature $15^{\circ} \mathrm{C}$. The ingredients were mixed with a $3 / 4$ inch magnetic stir bar at 1000 RPM.

In experiments intended to produce $\mathrm{W} / \mathrm{C}$ emulsions, first the dry mineral is added to the HPBR, followed by injection of liquid $\mathrm{CO}_{2}$. After agitation, a high pressure syringe pump is used to inject water to a set pressure of 17.2 MPa. For the W/C emulsions, we used a proportion of approximately $65 \mathrm{~mL} \mathrm{CO}_{2}: 20 \mathrm{~mL} \mathrm{H}_{2} \mathrm{O}$.

\section{(b) In-house Preparation of Fine Particles}

Comminution of mineral particles is achieved in a low speed 4 qt. Patterson-Kelley Vcone wet/dry blender charged with approx. $200 \mathrm{~g}$ of mineral, $500 \mathrm{~mL}$ of water, and $200 \mathrm{~g}$ of 3/8" diameter silicon nitride grinding pebbles. After the desired processing time has elapsed (typically 8-72 hr), the pulverized mineral is recovered by Büchner filtration and the filter cake is air-dried.

\section{(c) Materials}

Sand. Ordinary sand was collected on a beach of Cape Cod, Massachusetts. The sand is ground into powder with the aforementioned blender. The dried powder is sieved through a US mesh 325 sieve. The sieve lets through particles that are smaller than about $45 \mu \mathrm{m}$. Carbon Black. Carbon black was obtained from Cabot Corp. 100 \% carbon, 120 nm average particle size. It is used for emulsion formation without further processing. Pulverized Coal. Pulverized coal was obtained from the Salem Harbor Station coal-fired power plant. The coal is of Colombian origin, bituminous, dried, $65 \%$ carbon, $6.6 \%$ ash. The coal was pulverized in a ball mill at the power plant. About $45 \%$ of the coal dust passes a US mesh 325 sieve, which means that about $45 \%$ of the coal particles are smaller than about $45 \mu \mathrm{m}$. 
Teflon. Teflon powder is commonly used for lubricating purposes. We purchased tens of grams from a retail store. The claimed average particle size is $10 \mu \mathrm{m}$. The powder was used without further processing.

\section{RESULTS}

\section{(a) $\mathrm{CO}_{2}$-in-Water Emulsion (C/W)}

Pulverized Sand. A Scanning Electron Microscope (SEM) photo of the sand powder is shown in Figure 1 . The sand particles are mostly crystalline, probably quartz, average size $10 \mu \mathrm{m}$. An Energy Dispersive X-ray (EDX) analysis focused on one of the sand particle showed that its composition is mainly silica, $\mathrm{SiO}_{2}$. Silica is hydrophilic, so it is expected to form a $\mathrm{CO}_{2}$-in-Water $(\mathrm{C} / \mathrm{W})$ emulsion, where the $\mathrm{CO}_{2}$ droplets constitute the dispersed (internal) phase, and water the continuous (external) phase.

The formed macro-emulsion is a C/W-type, with clearly discernable $\mathrm{CO}_{2}$ droplets sheathed with sand particles. The average sheathed droplet size is $200-300 \mu \mathrm{m}$. The emulsion was stable for at least one hour of observational period. A video photo of the emulsion taken after mixing and several minutes of rest is shown in Figure 2. A part of the sheathed droplets settled in the bottom of the cell; another part is still floating in the water column.

We have not yet taken a microscope video of the sand-sheathed $\mathrm{CO}_{2}$ droplets. Instead, in Figure 3 we show a $40 \mathrm{X}$ magnification of $\mathrm{CO}_{2}$ droplets sheathed with Fisher Chemicals C-65 pulverized $\mathrm{CaCO}_{3}$. The sheathed droplet size is in the $500-800 \mu \mathrm{m}$

range. The sheath consists of a monolayer of $\mathrm{CaCO}_{3}$ particles at the $\mathrm{CO}_{2} / \mathrm{H}_{2} \mathrm{O}$ interface of approximately $20 \mu \mathrm{m}$ thickness.

\section{(b) Water-in-CO $\mathrm{O}_{2}$ Emulsion (W/C)}

Carbon Black. Carbon Black (CB) is hydrophobic. CB is easily dispersed in a $\mathrm{CO}_{2} / \mathrm{H}_{2} \mathrm{O}$ mixture, but due to its colloidal nature, the dispersion remains opaque and cannot be meaningfully photographed. However, no $\mathrm{CO}_{2} / \mathrm{H}_{2} \mathrm{O}$ phase separation was evident over multiple hours of observational period, suggesting that a W/C-type emulsion was formed with $\mathrm{H}_{2} \mathrm{O}$ droplets sheathed with $\mathrm{CB}$ particles dispersed in $\mathrm{CO}_{2}$. Teflon. Teflon is very hydrophobic. It is easily dispersed in a $\mathrm{CO}_{2} / \mathrm{H}_{2} \mathrm{O}$ mixture. Evidently, a W/C-type emulsion was formed with $\mathrm{H}_{2} \mathrm{O}$ droplets sheathed with Teflon particles. Because of the high emulsification efficiency of Teflon, only $1 \mathrm{~g}$ of the powder is necessary to completely sheath the $\mathrm{H}_{2} \mathrm{O}$ droplets. A video photo of the resulting emulsion is shown in Figure 4(a), and a close-up of the sheathed droplets is shown in Figure 4(b).

Pulverized Coal. Pulverized coal (PC) as received from a local power plant was suspended in water. The coal particles formed a W/C-type emulsion with sheathed $\mathrm{CO}_{2}$ droplet size in the $80-120 \mu \mathrm{m}$ range. A video photo of the resulting emulsion is shown in Figure 5.

\section{(c) Effect of Impurities on Emulsion Formation}

Methanol. Commercial physical absorbents for $\mathrm{CO}_{2}$ capture after coal gasification are mostly based on methanol $(\mathrm{MeOH})$. Some of the $\mathrm{MeOH}$ may be captured together with $\mathrm{CO}_{2}$. It is important to show whether the presence of $\mathrm{MeOH}$ in liquid $\mathrm{CO}_{2}$ will affect the 
emulsion formation process. We mixed $5 \%$ by volume of $\mathrm{MeOH}$ to liquid $\mathrm{CO}_{2}$ before introducing it to the HPBR containing the slurry of $\mathrm{CaCO}_{3}$ in water. $\mathrm{A} \mathrm{C} / \mathrm{W}$-type macroemulsion formed with average sheathed $\mathrm{CO}_{2}$ droplet size in the $200-300 \mu \mathrm{m}$ range. A video photo of the resulting emulsion is shown in Figure 6.

Monoethanolamine. Commercial chemical absorbents for $\mathrm{CO}_{2}$ capture after combustion are mostly based on monoethanolamine (MEA). Some of the MEA may be captured together with $\mathrm{CO}_{2}$. It is important to show whether the presence of MEA in liquid $\mathrm{CO}_{2}$ will affect the emulsion formation process. We added 5\% by volume of MEA to the water used for preparing the slurry of $\mathrm{CaCO}_{3}$. Liquid $\mathrm{CO}_{2}$ was added to the HPBR as usual. A C/W-type macro-emulsion formed with average sheathed $\mathrm{CO}_{2}$ droplet size in the $100-180 \mu \mathrm{m}$ range. A video photo of the resulting emulsion is shown in Figure 7. Sodium Chloride. For ocean sequestration of $\mathrm{CO}_{2}$ it is important to determine whether seawater salinity would affect the formation of an emulsion. We used artificial seawater consisting of a solution of 3.5\% by weight of $\mathrm{NaCl}$ in de-ionized water and Hubercarb Q6 pulverized limestone. As seen from Figure 8, the macro-emulsion appeared similar to the one using de-ionized water without $\mathrm{NaCl}$. This indicates that salt, at concentration levels in seawater, has no apparent effect on the $\mathrm{CO}_{2} / \mathrm{H}_{2} \mathrm{O} / \mathrm{CaCO}_{3}$ macro-emulsion formation..

\section{DISCUSSION}

For ocean sequestration we are interested in forming a $\mathrm{CO}_{2}$-in-Water $(\mathrm{C} / \mathrm{W})$ macroemulsion, where $\mathrm{CO}_{2}$ is the dispersed (internal) phase, and $\mathrm{H}_{2} \mathrm{O}$ is the continuous (external) phase. The macro-emulsion is stabilized by fine particles. According to our experiments, pulverized limestone, sand, some abundant minerals (e.g. olivine and serpentine), and flyash can be used for forming a macro-emulsion. We reported in the previous semi-annual report that a particle stabilized macro-emulsion is denser than ambient seawater. From experiments in the DOE/NETL water tunnel facility (Golomb et al., 2005), we determined that the macro-emulsion has a gross density of $1.084 \mathrm{~kg} \mathrm{~m}^{-3}$, and the individual sheathed droplets have a density of $1.07 \mathrm{~kg} \mathrm{~m}^{-3}$. The average density of seawater at $500 \mathrm{~m}$ is about $1.03 \mathrm{~kg} \mathrm{~m}^{-3}$ (Teng et al., 1996). Therefore, upon release the emulsion plume would sink deeper from the injection point. A minimum injection depth is considered to be $500 \mathrm{~m}$, because above this depth, the sheathed $\mathrm{CO}_{2}$ droplets would disintegrate, and liquid $\mathrm{CO}_{2}$ would flash into vapor. The vapor bubbles would rise to the surface and re-emerge into the atmosphere. Depths of approximately $500 \mathrm{~m}$ are reached within a relatively short distance (less than $100-200 \mathrm{~km}$ ) from the shores of many industrial countries, including the East, West and Gulf Coasts of the USA. In contrast, the minimum depth of pure, liquid $\mathrm{CO}_{2}$ injection is considered to be at least $1000 \mathrm{~m}$ in order for the positively buoyant $\mathrm{CO}_{2}$ droplets to dissolve in seawater before they flash into vapor at about $500 \mathrm{~m}$ (Herzog et al., 1991). Thus, the injection of a dense macroemulsion would save the cost and difficulty of laying injection pipes to such depths.

In previous reports we have shown that macro-emulsions of $\mathrm{CO}_{2}$-in-Water $(\mathrm{C} / \mathrm{W})$ can be formed when stabilized with pulverized limestone, some minerals (olivine and serpentine), and unprocessed flyash as collected with an Electrostatic Precipitator (ESP). In this report we show that $\mathrm{C} / \mathrm{W}$-type macro-emulsions can also be formed with ordinary beach sand, provided the sand is pulverized to few to teens of $\mu \mathrm{m}$ size. Because sand is one of the most abundant materials on Earth, it may also be used for ocean sequestration 
of $\mathrm{CO}_{2}$. Because sand is a normal ingredient of bottom sediment, it is most likely innocuous to marine organisms. The economics of using pulverized sand for a $\mathrm{C} / \mathrm{W}$-type emulsion would consist mainly of the cost for transportation and milling of the sand.

In this report we described the formation of C/W-type emulsions in the presence of methanol, monoethanolamine and $\mathrm{NaCl}$. The former are possible impurities that are captured together with $\mathrm{CO}_{2}$ from fossil fuel combustion, and $\mathrm{NaCl}$ is an ingredient of seawater. At concentrations of up to $5 \%$ by volume of $\mathrm{MeOH}$ and $\mathrm{MEA}$, and up to 3.5\% by weight of $\mathrm{NaCl}$, these impurities do not seem to have an effect of $\mathrm{C} / \mathrm{W}$-type macroemulsion formation.

Carbon dioxide-in-water emulsions may also find use for geologic sequestration. Upon release in the geologic repository, for example, in a deep saline aquifer, the C/Wtype emulsion may spread in the bottom of the reservoir, because it is denser than brine. This may prevent the buoying upward ("fingering") of $\mathrm{CO}_{2}$, with possible leakage into upper strata, and re-emergence into the atmosphere. For geologic sequestration, it may be necessary to form a micro-emulsion, using ultra-fine particles, so that the particles will not clog the pores and throats of the reservoir. In the extension of the Co-operative Agreement, we plan to form particle-stabilized micro-emulsions using micro-fluidizers and very fine particles of the order of sub- to a few $\mu \mathrm{m}$ in size.

For specific geologic sequestration, e.g. in semi-depleted oil reservoirs, it may be advantageous to use a Water-in- $\mathrm{CO}_{2}(\mathrm{~W} / \mathrm{C})$ emulsion, where $\mathrm{H}_{2} \mathrm{O}$ is the dispersed (internal) phase, and $\mathrm{CO}_{2}$ is the continuous (external) phase. This would enable the rapid dissolution of $\mathrm{CO}_{2}$ in the remaining kerogen of the reservoir. In this report we described the initial experiments of forming W/C-type emulsions using carbon black, Teflon and pulverized coal particles. Such experiments will continue in the following budgetary periods.

\section{PLANS FOR THE NEXT PERIOD}

\section{(a) Apparatus Additions and Modifications}

Purchase and install Jerguson cell with windows on outlet of static mixer for optical observations of emulsion exiting the mixer

\section{(b) Measurements in High Pressure Batch Reactor}

- Investigate the effects of impurities on globulsion formation

$$
\begin{array}{ll}
- & \mathrm{H}_{2} \mathrm{~S} \\
- & \mathrm{NO}_{\mathrm{x}} \\
- & \mathrm{SO}_{2}
\end{array}
$$

- Investigate emulsion formation with various grade and particle sizes of pulverized limestone

- Investigate emulsion formation with various pulverized minerals, e.g. clay and shale, and repeat experiments with olivine

- Obtain Scanning Electron Microscope (SEM) photos of residual sheath particles after evaporation of $\mathrm{CO}_{2}$ and $\mathrm{H}_{2} \mathrm{O}$ and compare with SEM of original particles 


\section{(c) Measurements in High Pressure Flow Reactor with Static Mixer}

- Investigate emulsion characteristics ensuing from static mixer using various grade and particle sizes of pulverized limestone

- Investigate emulsion characteristics ensuing from static mixer using various grade and particle sizes of sand

- Investigate emulsion characteristics ensuing from static mixer using artificial or real seawater

- Make measurements at low temperatures in the regime where hydrate formation may interfere with emulsion formation

- Investigate W/C-type emulsion formation using the static mixer

\section{CONCLUSIONS}

Research in the previous semi-annual reports has shown that stable C/W-type macroemulsions can be formed when liquid or supercritical carbon dioxide and pulverized limestone $\left(\mathrm{CaCO}_{3}\right)$, flyash and certain minerals (olivine and serpentine) are mixed with pure or artificial seawater. In this report we have shown that stable C/W-type emulsions can also be formed with pulverized beach sand. For the first time optical microscopy was used to show the structure of the particle-sheathed $\mathrm{CO}_{2}$ droplets. It is shown that the droplets are sheathed with a monolayer of particles. The particle sheath evidently is preventing the $\mathrm{CO}_{2}$ droplets to coalesce into a bulk phase.

In this report we describe the formation of W/C-type emulsions using pulverized carbon black, coal and Teflon. The W/C-type emulsions may find use in geologic sequestration, such as in saline aquifers and semi-depleted oil reservoirs.

\section{REFERENCES}

Herzog, H., D. Golomb and S. Zemba, Environmental Progress, 10, 64-74, 1991. Swett, P., D. Golomb, E. Barry, D. Ryan, C. Lawton, Proceedings of the 7th International Conference on Greenhouse Gas Control Technologies, GHGT-7, Vancouver, BC, Canada, 2004.

Teng, H., A. Yamasaki and Y. Shindo, Energy, 21, 765-774, 1996.

\section{PUBLICATIONS}

D. Golomb, E. Barry, D. Ryan, C. Lawton, P. Swett, D. Arora "Limestone Emulsion to Alleviate Concerns about Deep Ocean Storage of $\mathrm{CO}_{2}$ " Poster paper presented at the Second Annual Conference on Carbon Sequestration, Alexandria, VA, May 5-9, 2003. D. Golomb, E. Barry, D. Ryan, C. Lawton, P. Swett "Limestone Particle Stabilized Macro-emulsion of Liquid and Supercritical Carbon Dioxide in Water for Ocean Sequestration,” Environmental Science and Technology, 38, 4445-4450, 2004. P. Swett, D. Golomb, E. Barry, D. Ryan, C. Lawton "Liquid Carbon Dioxide/Pulverized Limestone Globulsion for Deep Ocean Storage,” Paper presented at the 7th International Conference on Greenhouse Gas Control Technologies, GHGT-7, Vancouver, BC, Canada, Sep 5-9, 2004.

D. Golomb, E. Barry, D. Ryan, C. Lawton, P. Swett, R. Warzinski and R. Lynn " $\mathrm{CO}_{2}$-inWater Emulsion Stabilized by Pulverized Limestone for Benign Ocean Storage,” Paper presented at the IVth Annual Conference on Carbon Capture and Sequestration, May 2-5, 2005, Alexandria, VA. 


\section{ILLUSTRATIONS}

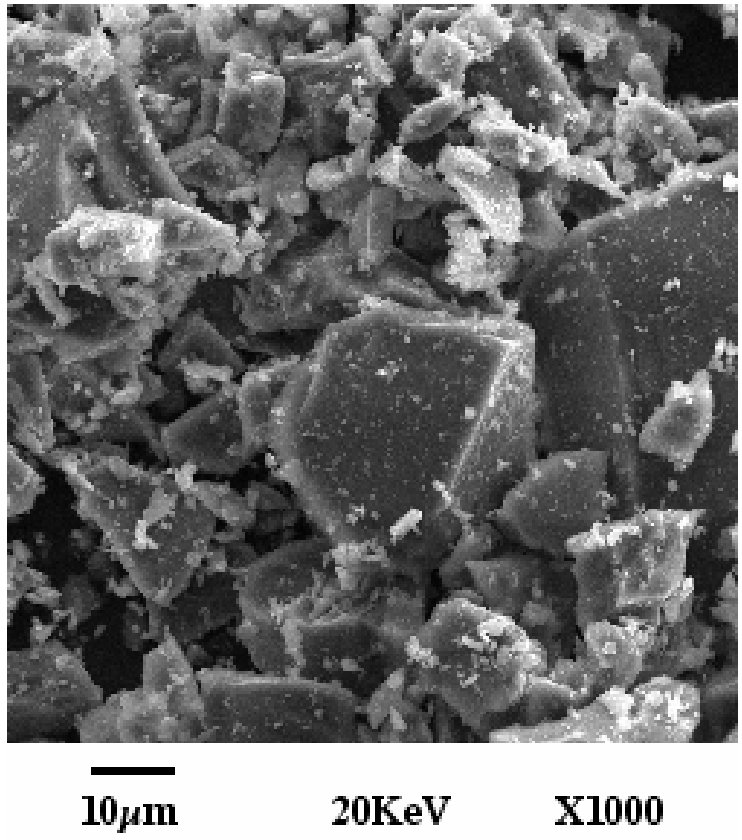

FIGURE 1. Scanning Electron Micrograph of Pulverized Beach Sand

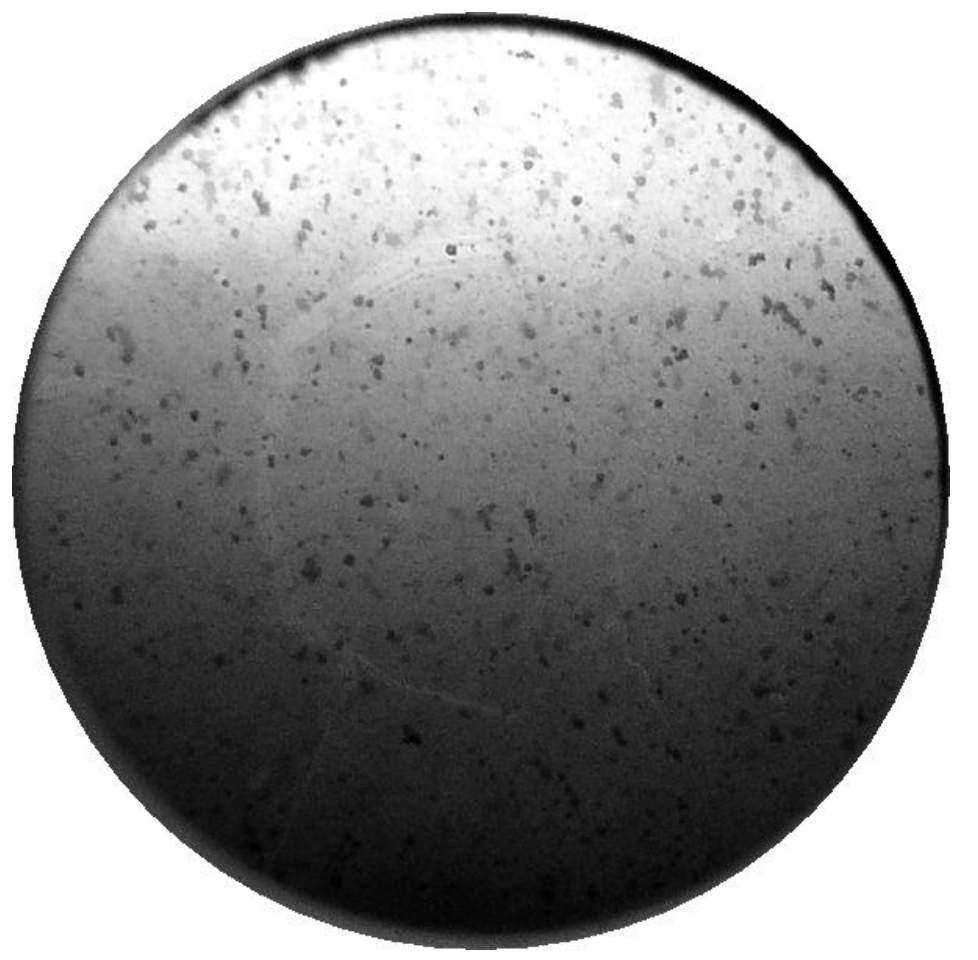

FIGURE 2. $\mathrm{CO}_{2}$-in-Water Emulsion Stabilized by Pulverized Sand Particles 


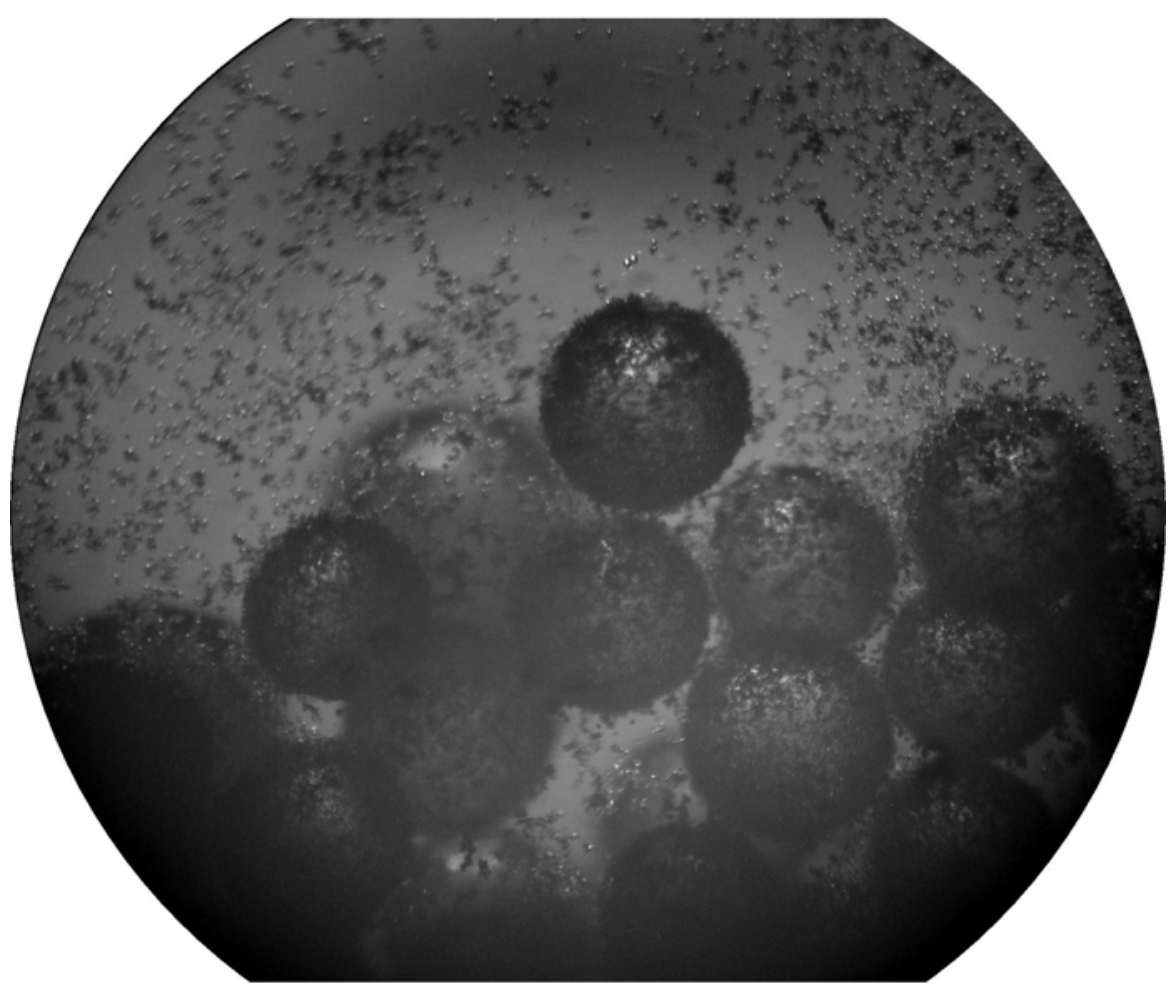

FIGURE 3. Microscopy of $\mathrm{CO}_{2}$-in-Water Emulsion Stabilized by Limestone Particles. Magnification approx. 40X.

a)

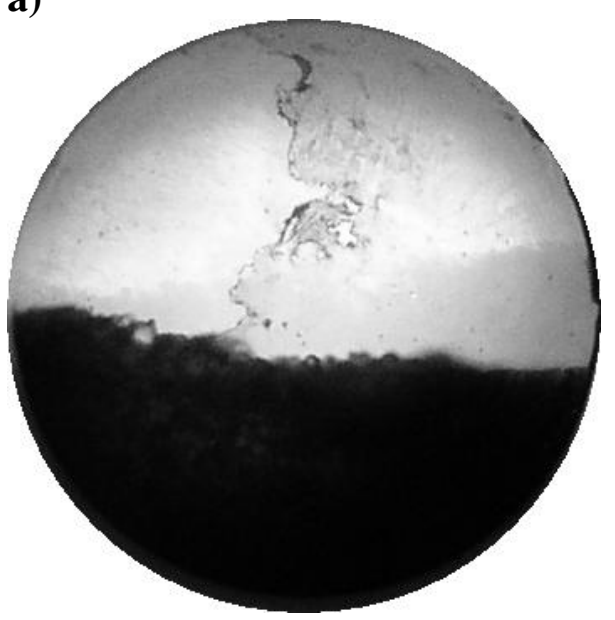

b)

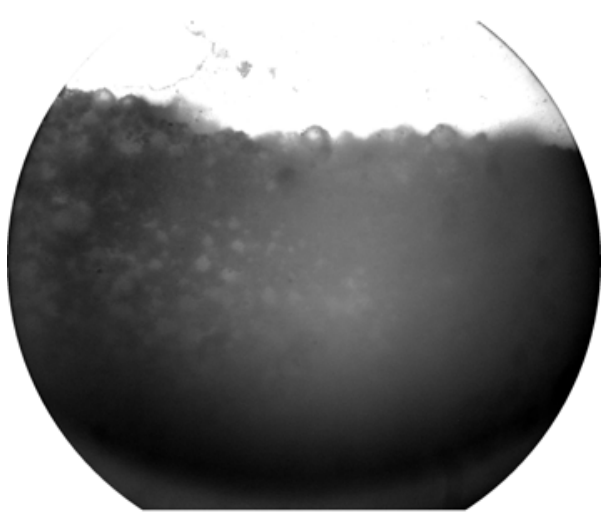

FIGURE 4. (a) Water-in- $\mathrm{CO}_{2}$ Emulsion Stabilized by Teflon Particles.

(b) Close-up of the Sheathed Water Droplets 


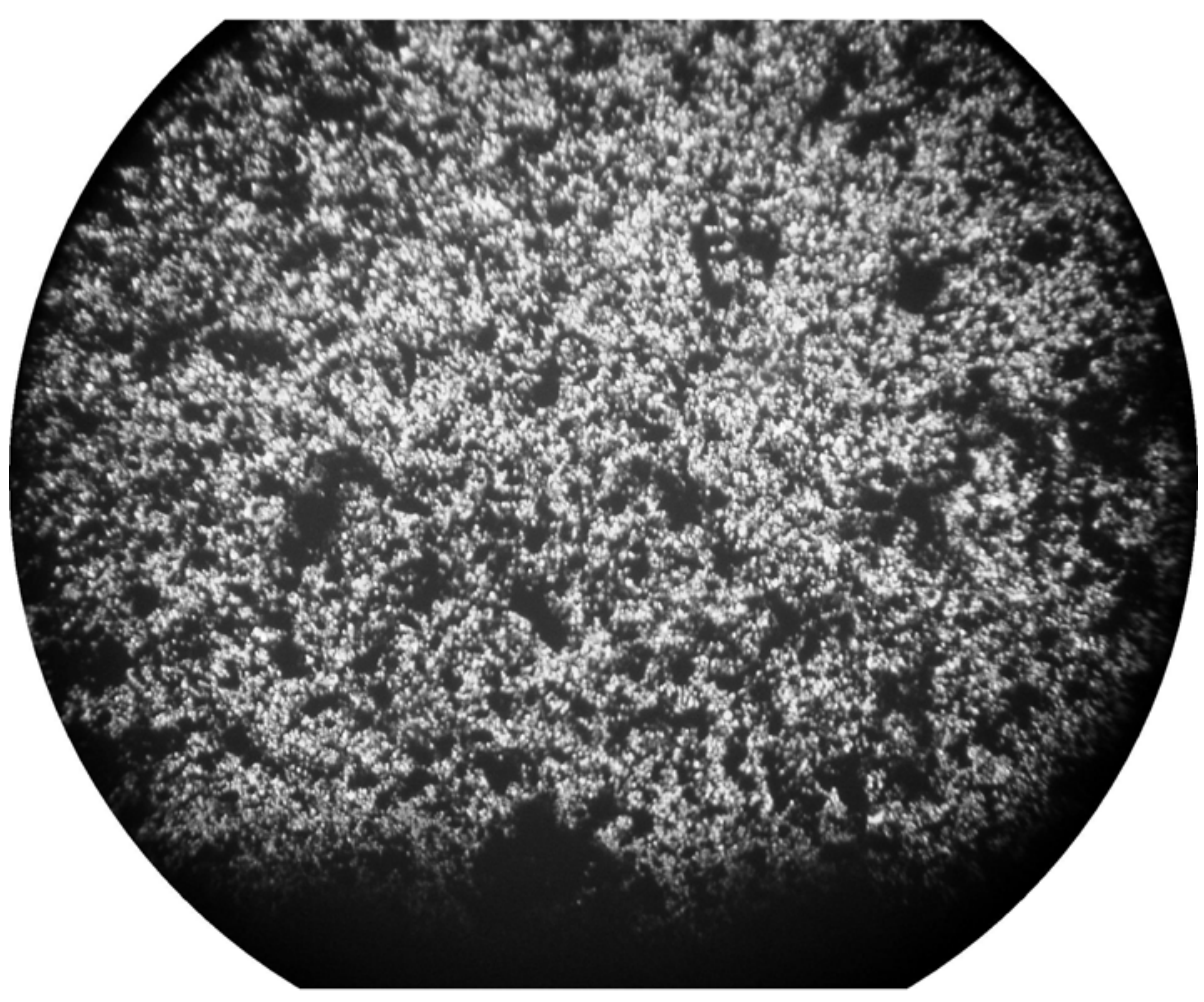

FIGURE 5. Water-in-CO${ }_{2}$ Emulsion Stabilized by Pulverized Coal Particles. 


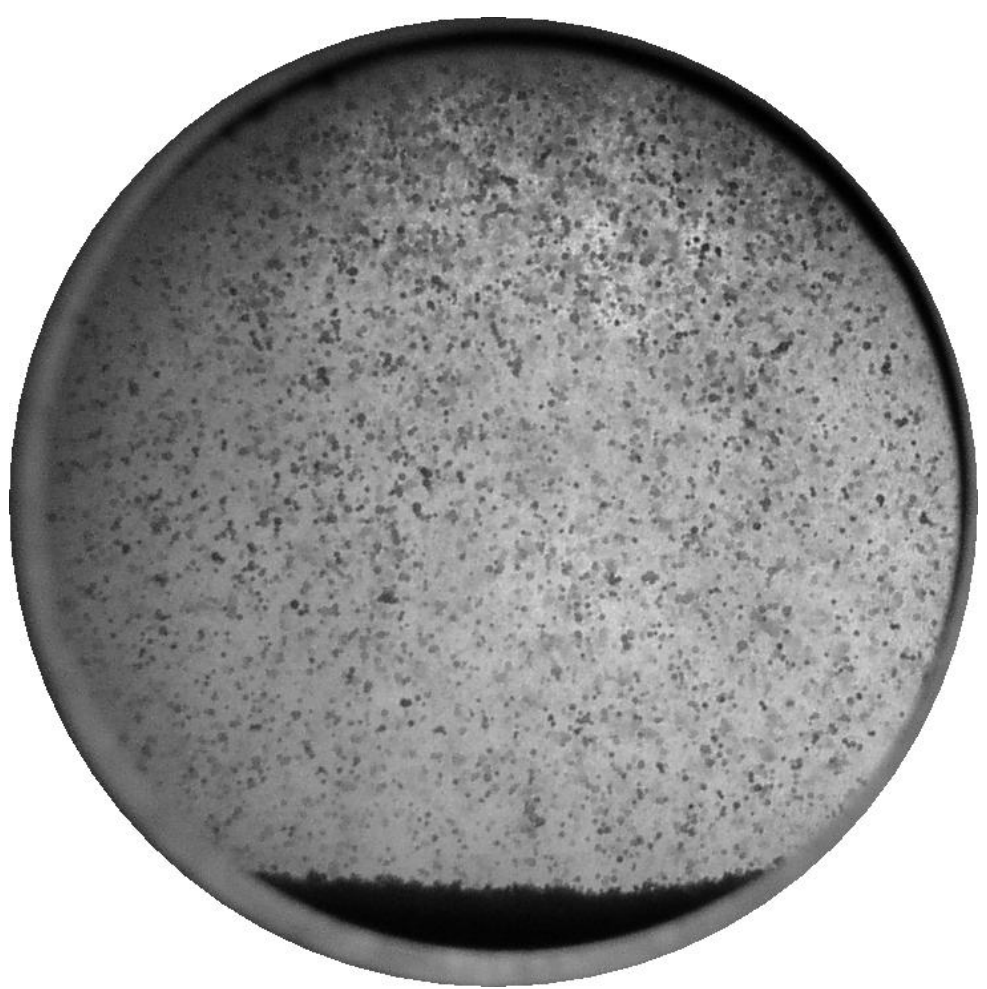

FIGURE 6. $\mathrm{CO}_{2}$-in-Water Emulsion Stabilized by $\mathrm{CaCO}_{3}$ Particles in the Presence of $\mathrm{MeOH}$.

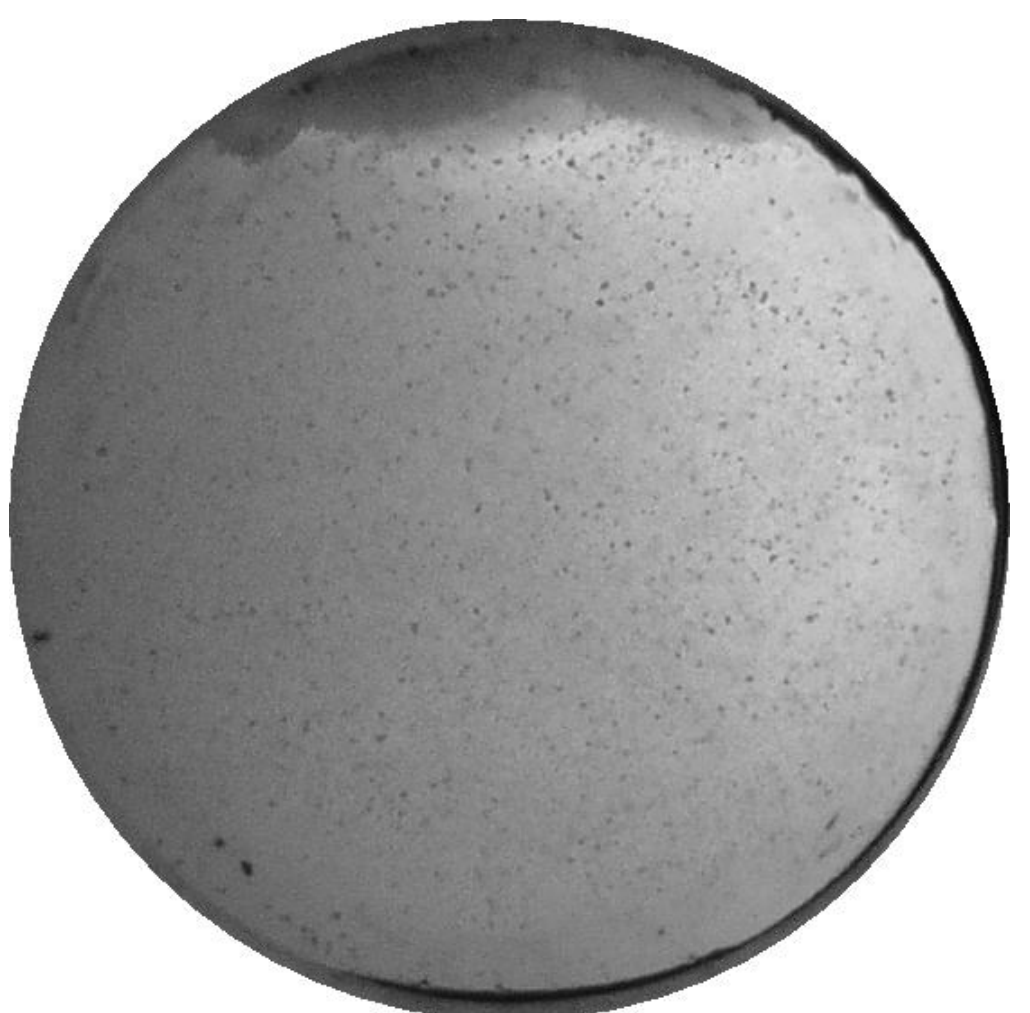

FIGURE 7. $\mathrm{CO}_{2}$-in-Water Emulsion Stabilized by $\mathrm{CaCO}_{3}$ Particles in the Presence of MEA. 


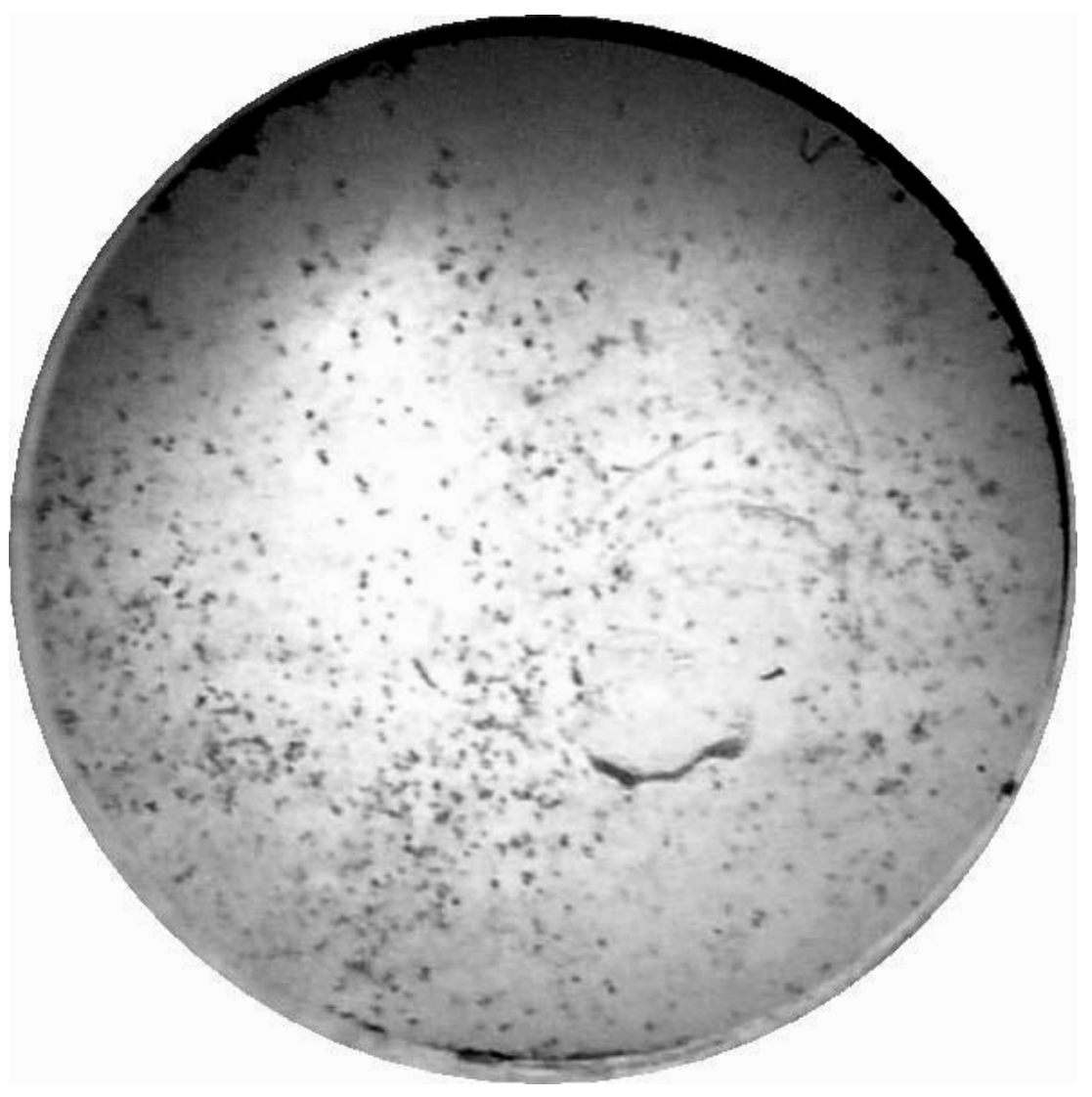

FIGURE 8. $\mathrm{CO}_{2}$-in-Water Emulsion Stabilized by $\mathrm{CaCO}_{3}$ in the Presence of Simulated Seawater. 